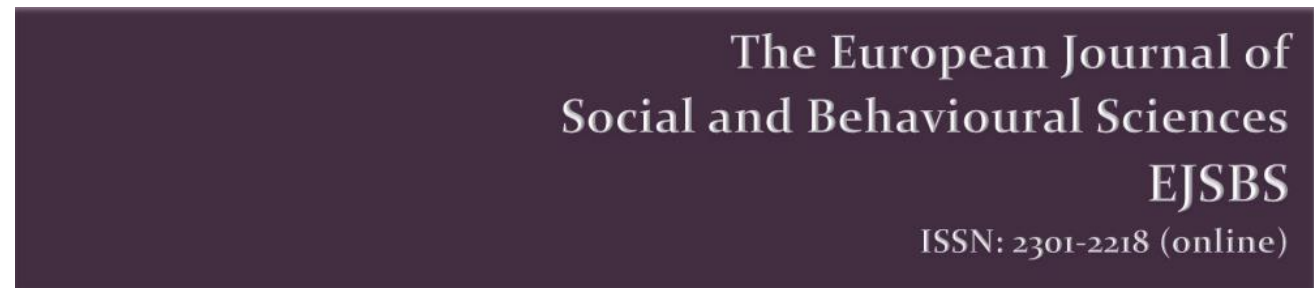

The European Journal of Social and Behavioural Sciences

EJSBS Volume III (e-ISSN: 2301-2218)

\title{
ROUSSEAU AS A PHILOSOPHER OF ENLIGHTENMENT AND THE EQUALITY OF SOPHIE AND ÉMILE REGARDING EDUCATION
}

\author{
Kamuran Godelek ${ }^{\mathrm{a} *}$
}

${ }^{a}$ Çă̆ University, Yaşar Bayboğan Campus,Tarsus, Yenice 33800, Mersin, Turkey

\begin{abstract}
J.J. Rousseau, while being an Enlightenment philosopher, is also known with his criticisms to the Enlightenment movement and basic ideas of modern philosophy. Rousseau, by rehashing the discussions brought upon by Descartes and his successors in the 18. century, pursued a social and political philosophy centered on the concepts of self and freedom. As the most controversial and paradoxical of the writers of the Enlightenment, Rousseau rejects both the Cartesian views, which reduces animals to a machine, a mere automaton with no feelings and also Ancient theses, which find the essence of humanity in the possession of reason. According to Rousseau, a human being defines oneself with both the power to squirm oneself out of the instinctual preprogramming, which means freedom, and also the power to have a history which has a priori, indefinite development. This human conception of Rousseau forms the foundation for not only for ethics but also for the politics and social life. Since, in the humanistic philosophy of Rousseau, human nature is not preprogrammed and there does not exist a single natural or social program that could compass a human being, each human being is free, who moves forward towards uncertainty and who has never been preprogrammed by the determinants related to race or gender. Rousseau argues that people who are educated according to the rules exerted by others, cannot be free; he outlines the main tenets of a freeing and perfective education in his influential work Emile with regard to the education of a boy named Emile. According to him, the question of "what a human being should do", that is, the question of how one to act in his/her relationship with others contains the question of "what a human being is" and consequently leads us to the reformation of social institutions through education. In the fourth chapter of the book which is about the moral education of Emile, Rousseau puts forward the Sophie character in order to show how different a woman's education should be contrasted to a man. Even though our human self is universally independent, Sophie is not quite as competent in theoretical issues as Emile; and Rousseau claims that the nature of the relationship between men and women stems from the fact that men are more powerful and independent. According to Rousseau, men are in need of women because they desire them, but women both desire men and also are in need of them. So, it seems that Rousseau's universal human self is not valid for women. Mary Wollstonecraft, a contemporary of Rousseau, in her book A Vindication of the Right of Women advocates the view that the education Rousseau withholds from women is a necessary right for women as well as for any human being. Wollstonecraft discovers the only reason for women's state is their lack of education. Relentlessly attacking Rousseau for limiting the education for active citizenship only to boys, consigning girls to a subservient "education for the body" alone, Wollstonecraft argues that even as mothers and nurturers, women require a much more substantial education. The aim of this paper is to investigate the faculties of freedom and perfection that Rousseau considers as necessary for a humanly existence and the idea of universality in terms of Sophie character by using Wollstonecraft's views.
\end{abstract}

Keywords: Rousseau, Emile, Sophie, Wollstonecraft, feminism, freedom, independence equal rights to education, philosophy of enlightenment

(C) 2012 Published by C-crcs. Peer-review under responsibility of Editor(s) or Guest Editor(s) of the EJSBS.

${ }^{*}$ Corresponding author.

E-mail address: kgodelek@cag.edu.tr

doi: 10.15405/FutureAcademy/ejsbs(2301-2218).2012.3.6

This work is licensed under a Creative Commons Attribution-NonCommercial-NoDerivatives 4.0 International License. 
https://doi.org/10.15405/FutureAcademy/ejsbs(2301-2218).2012.3.6

eISSN: 2301-2218 / Corresponding Autho: Kamuran Godelek

Selection \& Peer-review under responsibility of the Editors

\section{Introduction}

J.J. Rousseau, while being an Enlightenment philosopher, is also known with his criticisms to the Enlightenment movement and basic ideas of modern philosophy. Rousseau, by rehashing the discussions brought upon by Descartes and his successors in the 18. century, pursued a social and political philosophy centered on the concepts of self and freedom. As the most controversial and paradoxical of the writers of the Enlightenment, Rousseau rejects both the Cartesian views, which reduces animals to a machine, a mere automaton with no feelings and also Ancient theses, which find the essence of humanity in the possession of reason. According to Rousseau, a human being defines oneself with both the power to squirm oneself out of the instinctual preprogramming, which means freedom, and also the power to have a history which has a priori, indefinite development.

This human conception of Rousseau forms the foundation for not only for ethics but also for the politics and social life.

Since, in the humanistic philosophy of Rousseau, human nature is not preprogrammed and there does not exist a single natural or social program that could compass a human being, each human being is free, who moves forward towards uncertainty and who has never been preprogrammed by the determinants related to race or gender.

Rousseau argues that people who are educated according to the rules exerted by others, cannot be free; he outlines the main tenets of a freeing and perfective education in his influential work Émile with regard to the education of a boy named Émile.

According to him, the question of "what a human being should do", that is, the question of how one to act in his/her relationship with others contains the question of "what a human being is" and consequently leads us to the reformation of social institutions through education. In the fourth chapter of the book which is about the moral education of Émile, Rousseau puts forward the Sophie character in order to show how different a woman's education should be contrasted to a man.

Even though our human self is universally independent, Sophie is not quite as competent in theoretical issues as Émile; and Rousseau claims that the nature of the relationship between men and women stems from the fact that men are more powerful and independent. According to Rousseau, men are in need of women because they desire them, but 
https://doi.org/ 10.15405/FutureAcademy/ejsbs(2301-2218).2012.3.6

eISSN: 2301-2218 / Corresponding Autho: Kamuran Godelek

Selection \& Peer-review under responsibility of the Editors

women both desire men and also are in need of them. So it seems that Rousseau's universal human self is not valid for women.

Mary Wollstonecraft, a contemporary of Rousseau, in her book A Vindication of the Right of Women advocates the view that the education Rousseau withholds from women is a necessary right for women as well as for any human being.

Wollstonecraft discovers the only reason for women's state is their lack of education. Relentlessly attacking Rousseau for limiting the education for active citizenship only to boys, consigning girls to a subservient "education for the body" alone, Wollstonecraft argues that even as mothers and nurturers, women require a much more substantial education.

\section{Purpose of the Study}

The aim of this paper is to evaluate Rousseau's theory of education by investigating how his treatment of the faculties of freedom and perfection, which Rousseau considers as necessary for a humanly existence, differs for Émile and Sophie in terms of Wollstonecraft's views.

\section{Research Methods Rousseau on Human Nature and Education}

Rousseau, while being an Enlightenment philosopher, he also played an important role in the birth of Romanticism. Rousseau's political and social philosophy influenced his views on morality and education. The major philosophical shift that occurred in the Enlightenment was a turning away from revelation (the Bible) as the authoritative source of absolute truth and the embrace of human reason as the source of truth.

The Enlightenment philosophers embraced Natural Law as the primary way of understanding human relations. Natural Law is the concept that God's laws are embedded in nature and if we just observe man in the primitive state we will see the behaviors that are universal among all people and we can enact laws based on these principles. In line with this conception, Rousseau held the view that the supposed correlation between knowledge and virtue was mistaken.

Rousseau's views on the human nature and the relationship between society and the individual are also influenced by Romantic vision. Romantic vision can be described as:

The 'Romantic' is said to favour the concrete over the abstract, variety over uniformity, the infinite over the finite; nature over culture, convention and artifice; the organic over the mechanical; freedom over constraint, rules and limitations. In human terms it prefers the unique individual to the average person, the free creative genius to the prudent person of good sense, the particular community or nation to humanity at large. Mentally, the Romantics prefer feeling 
https://doi.org/10.15405/FutureAcademy/ejsbs(2301-2218).2012.3.6

eISSN: 2301-2218 / Corresponding Autho: Kamuran Godelek

Selection \& Peer-review under responsibility of the Editors

to thought, more specifically emotion to calculation; imagination to literal common sense, intuition to intellect. (Quinton 1996, p. 778)

As it is easy to see from this passage, the tension between the individual and society, solitude and association, which are the main themes and concerns in Rousseau's work are associated with his romanticism. In his essay Discourse on Arts and Sciences, which was awarded a first prize by the Academy of Dijon, Rousseau argued that virtue and ignorance are correlated and so were vice and knowledge.

Assuming that humans are by nature are good and it is the society's institutions that corrupt them, he claimed that knowledge had been deployed to make people behave pleasingly rather than virtuously by moulding their actions in order to hide their dispositions. Rousseau envisages humans in the state of nature as solitary beings. They are non-linguistic and meet infrequently and contact between individuals is limited to casual encounters. Over time, however, humans abandon their solitary lifestyle, driven largely by material need. According to him, human beings are inherently good, it is the evils of society what makes them corrupt.

Later in his Discourse on Inequality published in 1754, which is one of the most revolutionary documents of the eighteenth century, he seeks to show how the growth of civilization corrupts man's natural happiness and freedom by creating artificial inequalities of wealth, power and social privilege. Rousseau contends that primitive man is equal to his fellows because he can be independent of them, but as societies become more sophisticated, the strongest and most intelligent members of the community gain an unnatural advantage over their weaker brethren, and the constitutions set up to rectify these imbalances through peace and justice in fact do nothing but perpetuate them. What's really worth to emphasize here is that Rousseau's argument demonstrates the relationship between social inequality and the possession of property. It also offers a means of accounting for the evils of human life without presupposing a corrupt or selfish human nature. In fact, Rousseau takes the contrary view. Humans in their purportedly savage state are for him essentially good, in that they are all equipped with natural compassion. "If human nature cannot be held responsible for the corruption that is present in modern society, then it follows that it is so-called civilization itself that ought to be regarded as the genuine cause of human misery" (Edgar \& Sedgwick, 2002, p. 216).

Rousseau's belief that humans are corrupted by the society is also expressed in the famous statement in the opening paragraph of his classic book on political theory The Social Contract: "Man was born free, and he is everywhere in chains" (2002, p. 156). The Social Contract presents Rousseau's most radical contribution to the debate about the nature of government: his notion of the "general will". 
https://doi.org/10.15405/FutureAcademy/ejsbs(2301-2218).2012.3.6

eISSN: 2301-2218 / Corresponding Autho: Kamuran Godelek

Selection \& Peer-review under responsibility of the Editors

This general will is supposed to represent the common good or public interest, and it is something that all citizens should be committed to participate even if it means acting against their private or personal interests. In a much-cited passage from The Social Contract, Rousseau says that dissenters from the general will "shall be forced to be free" (2002, Book I, p. 175). This way of living, he argued, can promote liberty and equality, and it arises out of and fosters a spirit of fraternity.

Émile complements Rousseau's conception of humans in his two of other major works the Discourse on Inequality and the Social Contract. "These three constitute the axes of Rousseau's idea of formation. The formation of the human race is the axis of the Second Discourse [Discourse on Inequality], the formation of the individual that of the Emile, and the formation of the citizen that of the Social Contract." (O'Hagan, 1999, pp. 6-7). The three axes are linked by Rousseau's insight that "we must study society by men and men by society. Those who want to treat politics and morality separately will never understand anything about either of them" (Rousseau, 1979, IV, p. 235).

Rousseau primarily believes that nature has created man happy and good, but society depraves him and makes him miserable.

All of Rousseau's educational theories derive from his attempt to preserve nature's pure state. Hence, the basic philosophy of education that Rousseau advocates in the Émile, much like his thought in the first two Discourses, is rooted in the notion that human beings are good by nature. The focus of Émile is upon the individual tuition of a boy or a young man in line with the principles of natural education. In accord with the ideology of Enlightenment, Rousseau believes that the appropriate education for a good citizen should provide a way of living, which promotes liberty and equality. Within education, his main contribution is emphasis on child centered education with his attendant emphasis on the freedom of the child to develop at his own appropriate pace and on learning by discovery rather than by the forms of imposition.

Rousseau's general pedagogical method, in accord with this emphasis, is to cultivate the pupil's natural powers and capacities to the maximum while minimizing the weaknesses and vices traditionally associated with the education of children. In the case of Émile, the goal of his education is to perfect his physical and intellectual abilities without jeopardizing his natural state of happiness and goodness. So, the education is geared towards maximizing the development of his physical and most of his mental capacities and minimizing the socially engendered desire to be esteemed by others. 
https://doi.org/10.15405/FutureAcademy/ejsbs(2301-2218).2012.3.6

eISSN: 2301-2218 / Corresponding Autho: Kamuran Godelek

Selection \& Peer-review under responsibility of the Editors

According to Rousseau, the original nature of the child could only be preserved by a careful control of his education and environment based on analysis of the different physical and psychological stages through which he passed from birth to maturity.

The fundamental point of his philosophy of education is his emphasis on preserving the original perfect nature of the child. He believes that the momentum for learning could be provided by the growth of person or his nature and all that the educator needs to do is to facilitate opportunities for learning. For this reason, he advocates the notion of negative education aimed at not direct instruction, but instead at providing to provide an encouraging environment for the child to reason his own way through to his own conclusions without having to rely on the authority of the instructor. His concept of negative education allowed a child to discover for himself and to be punished by the nature he sought to defy. The tutor must not try to reason with the child or show authority.

Books would not be forced on the child; at twelve Émile would hardly know what to do with a book. Positive education, or direct instruction, would only begin at approximately the age of adulthood, and then the studies would be based on the student's natural curiosity. Rousseau stressed utility, the need for teaching things with practical applications.

This concept of negative education as applicable to women is totally inconceivable to Rousseau. According to him education of girls is similar to boys in regard to naturalness but different because of gender. He introduces the character of Sophie as a future wife of Émile, and explains how her education differs from Émile's. Hers is not as focused on theoretical matters, as men's minds are more suited to that type of thinking. In his own words:

In the union of the sexes each contributes equally to the common aim. but not in the same way. From this diversity arises the first assignable difference in the moral relations of the two sexes. One ought to be active and strong, the other passive and weak. One must necessarily will and be able; it suffices that the other put up little resistance. Once this principle is established, it follows that woman is made specially to please man. If man ought to please her in turn, it is due to a less direct necessity. His merit is in his power; he pleases by the sole fact of his strength. This is not the law of love, I agree. But it is that of nature, prior to love itself (Rousseau, 1979, V, p. 358).

Rousseau claims that a girl cannot be educated to be a man. He stresses freedom of movement and physical exertion for Émile, asserting that weak bodies contain weak minds. At the same time, he discourages Sophie from too much physical activity and uses her weakness as another proof for her inferiority. Sophie should be educated to be a good wife to Émile, aa good mother and the center of the family. Because a woman should always be in subjection to man, "a woman's education must be planned in relation to man" (Rousseau, 1979: 361). Sophie 
https://doi.org/10.15405/FutureAcademy/ejsbs(2301-2218).2012.3.6

eISSN: 2301-2218 / Corresponding Autho: Kamuran Godelek

Selection \& Peer-review under responsibility of the Editors

is educated in such a way that she will fill what Rousseau takes to be her natural role as a wife. She is to be submissive to Émile. Although Rousseau advocates these very specific gender roles, it would be a mistake to take the view that Rousseau regards men as simply superior to women. Women have particular talents that men do not; Rousseau says that women are cleverer than men, and that they excel more in matters of practical reason (age: 398-400).

But, as Susan Shell, a feminist critic of Rousseau, rightly points out:

Émile's education is accomplished through a hidden regulation on the tutor's part that is so radical and comprehensive as to strain credulity if not altogether exceed the limits of the possible. Émile can be kept honest only by being surrounded by benevolent deception. What, then, is one to make of Sophie's education, which is mired in the proprieties and conventional, it seems, in almost all respects (Shell, 2006, p. 279).

It seems that sex differences between men and women that Rousseau thinks the only thing that separates these otherwise identical machines, proves to be all pervasive that men and women are educated differently according to their sexually conditioned roles. The consequence of this is that the education of women is diametrically opposed to the education of men, and yet, according to Rousseau, both are equally "natural"-quite a problematic view (Doyle \& Smith, 2007; Parry, 2006). This is exactly the point in Mary Wollstonecraft's attack on Rousseau for limiting the education for active citizenship only to boys, consigning girls to a subservient "education for the body" alone.

\section{Wollstonecraft on the Education of Women}

As a contemporary of Rousseau, education is critically important to Wollstonecraft both as a liberal reformer and a radical proponent of women's rights. In A Vindication of the Rights of Women, her famous and controversial book for her time, she pleas for a better education for women. This book is famous in feminist literature because it is a celebrated work on the causal relationship between rights and virtue. She demands for the civil and political rights that have been granted to men by French Revolution to be extended to women. As a self educated writer, Wollstonecraft is clearly dissatisfied when she discovers that negative education Rousseau advocates for Émile by claiming that "a genius will educate himself”, is not for the women, that as a woman she could never be such a man, that the genius mentioned in Émile can only be male: "I am now reading Rousseau's Emile, and love his paradoxes. He chooses a common capacity to educate - and gives as a reason, that a genius will educate itself - however he 
https://doi.org/10.15405/FutureAcademy/ejsbs(2301-2218).2012.3.6

eISSN: 2301-2218 / Corresponding Autho: Kamuran Godelek

Selection \& Peer-review under responsibility of the Editors

rambles into that chimerical world in which I have too often wandered - and draws the usual conclusion that all is vanity and vexation of spirit" (Wollstonecraft, 1796, p. 145).

Rousseau's standard for education for active citizenship developed throughout Émile is her main target. She argues that even in their traditional role as mothers and nurturers, however, women require a much more substantial education. Virtue must be "nursed by liberty," both positive freedom of intellectual inquiry and negative freedom from undue restraint (Wollstonecraft, 1796, p. 264).

The proper mother is not an amiable, fashionable house-slave but a reasonable, liberated intellectual. She treats Rousseau's description of Sophie with smug indignation, as when Rousseau describes Sophie's garb, "all this very simple attire was put on only to be taken off piece by piece by the imagination" (Rousseau, 1979, p. 394). To this she retorts: "Is this modesty? Is this a preparation for immortality?" (Wollstonecraft, 1796, p. 195). She rightly accuses Rousseau of depicting not a wife and a sensible mother, but a pleasing mistress.

Wollstonecraft's radical reconceptualization of the maternal role overlaps with the reformist agendas of most of the period's writers on education for women, but goes much further in demanding a complete overhaul of the "false system" recommended by "all" writers on "female education and manners" such as Rousseau. In place of incremental reforms, she calls for "civil" equality and economic independence, as well as an "independence of mind" scarcely to be expected from women "taught to depend entirely on their husbands" (Richardson, 2002, p. 33).

Wollstonecraft claims that:

The conduct and manners of women ... prove that their minds are not in a healthy state; ... One cause . . . I attribute to a false system of education, gathered from the books written on this subject by men who, considering females rather as women than human creatures, have been more anxious to make them alluring mistresses than affectionate wives and rational mothers; . . the understanding of the sex has been so bubbled by this specious homage, that the civilized women of the present century ... are only anxious to inspire love, when they ought to cherish a nobler ambition, and by their abilities and virtues exact respect. In a treatise, therefore, on female rights and manners, the works which have been particularly written for their improvement must not be overlooked; . . the books of instruction, written by men of genius, have had the same tendency as more frivolous productions ...(Wollstonecraft, 1796, pp. 1-2). 
https://doi.org/10.15405/FutureAcademy/ejsbs(2301-2218).2012.3.6

eISSN: 2301-2218 / Corresponding Autho: Kamuran Godelek

Selection \& Peer-review under responsibility of the Editors

Wollstonecraft does not advocate, nor has the desire to plea for a generation of independent and unattached women like herself, but she asks for a system of education that would allow to raise wiser and more virtuous mothers. She claims: "if children are to be educated to understand the true principle of patriotism, their mother must be a patriot; and the love of mankind, from which an orderly train of virtues spring, can only be produced by considering the moral and civil interest of mankind" (Wollstonecraft, 1796, p. 266). Because the character of the children forms before the age of seven, she thinks it is extremely important that they are raised by educated and liberated mothers. Without stressing independence, she believes that once women gain intellectual equality, they should also be given political and economic equality as well.

What is so radical about Wollstonecraft's idea is that girls are not educated relative to boys as Rousseau suggests for the education of Sophie, but rather that girls should be educated with boys. She states:

If marriage be the cement of society, mankind should all be educated after the same model, or the intercourse of the sexes will never deserve the name of fellowship, nor will women ever fulfill the peculiar duties of their sex. Nay, marriage will never be held sacred till women, by being brought up with men, are prepared to be their companions rather than their mistresses" (Wollstonecraft, 1796, pp. 380-81).

Wollstonecraft acknowledges the centrality of Rousseau to her vision of intellectual independence. Warning against the limitations of "mere instruction" she cites Rousseau in support of her assertion that, though the "sagacious parent or tutor may strengthen the body and sharpen the instruments by which the child is to gather knowledge... the honey must be the reward of the individual's own industry" (Wollstonecraft, 1796, pp. 177-183). Elsewhere in the same chapter, however, she vehemently attacks Rousseau for the "eager fondness" which leads him in Émile to exclude Sophie, and thus all women, from precisely that opportunity to exercise her own industry.

Wexler, examining the reasons behind Rousseau's unfortunate claim in Émile that "woman is made for man's delight" (Rousseau, 1976, p. 337) says that:

Early in Émile, Rousseau sets the scene for the education of independence through the control of emotions. He informs us that strength is the most desirable of virtues. Education, such as he describes, should make man stronger in the area he most needs to overcome his endemic weakness - control of the sexual urge. We will later learn that women, whom he confines to the home in order to preserve the society, do not need this type of education... The restrictions Rousseau wants to place on Sophie's education arise from adhering to what he observes as the commands of nature. Sophie's natural role in life is to be the object of Emile's 
https://doi.org/10.15405/FutureAcademy/ejsbs(2301-2218).2012.3.6

eISSN: 2301-2218 / Corresponding Autho: Kamuran Godelek

Selection \& Peer-review under responsibility of the Editors

pleasure and the faithful mother of his children; all laws that men make must conform to this rule (Wexler, 2001, pp. 272-273).

A Vindication of the Rights of Women is a manifesto for the rational independence for women. She considers the rational independence for women "a human ideal which she contrasts constantly with the gendered art of pleasing, through which, a certain kind of advice literature persuade its female readers, they will achieve power" (Jones, 2002, p. 138). Wollstonecraft is quite explicit about what kind of power she advocates for women: "I do not wish them to have power over men; but over themselves" (Wollstonecraft, 1796, p. 131). Hence the virtue of self control is central in Wollstonecraft's view of women's independence. Wollstonecraft often emphasizes, in her advice writing to women that the effect of gender is that "virtue becomes a relative idea, having no other foundation than utility, and of that utility men pretend arbitrarily to judge, shaping it to their own convenience" (Wollstonecraft, 1796, p. 120).

A Vindication of the Rights of Women is structured by the moralists's familiar opposition between superficiality and depth, and irresponsibility and duty. This is expressed in the sexualized juxtaposition of "alluring mistresses" with "affectionate views and rational mothers; and in Wollstonecrafts' concern that women should "exact respect" through the quality of their minds, "abilities and virtues", rather than remaining content simply to "inspire love" in men (Wollstonecraft, 1796, p. 103).

\section{Conclusions}

Rousseau's views on education are closely linked to his views on human nature so that the different treatments Emile and Sophie receive stem from and suitable to the differences from their nature. Rousseau also supposed, however, that mankind had a unique capacity to change its nature. While every other species of animal has been naturally provided with the instincts and capacities needed to sustain its life, human beings are by contrast free agents, capable of choice.

As distinct from creatures that are always enslaved by their appetites, people are endowed with free will and, as a consequence, at least the prospect of responsibility for determining how they live.

The lasting impact of Wollstonecraft's writing about education and childhood is also closely connected with her feminist ideas. Rational independence for women is the goal of Wollstonecraft's in her revolutionary work. 
https://doi.org/ 10.15405/FutureAcademy/ejsbs(2301-2218).2012.3.6

eISSN: 2301-2218 / Corresponding Autho: Kamuran Godelek

Selection \& Peer-review under responsibility of the Editors

"It was as a revolutionary thinker on female education, and its intimate relation to women's social, political and domestic subordination, that Wollstonecraft both inspired and provoked her contemporaries" (Richardson, 2002, p. 39). Her ideas about the independence and equal education rights for women still have an impact on education today, as well as Rousseau's revolutionary idea of natural education. Public education, teaching by the exploitation of natural curiosity, practical applications are all ideas descended from Rousseau and Wollstonecraft. However, the most distinctive of these contributions is Wollstonecraft's radical and revolutionary notion that women and men be educated together.

\section{Acknowledgements}

The authors declare that there is no conflict of interest.

\section{References}

Doyle, M. E., \& Smith, M. K. (2007). Jean Jacques Rousseau on Education. The Encylopaedia of Informal Education. http:/www.infed.org/thinkers/et-rous.htm

Edgar, A. \& Sedgwick, P. (2002). Cultural Theory The Key Thinkers, Routledge: London.

Jones, V. (2002). Mary Wollstonecraft and The Literature of Advice and Instruction. In C. Johnson (Ed.), The Cambridge Companion to Mary Wollstonecraft (pp. 119-140). Cambridge: Cambridge University https://doi.org/10.1017/CCOL0521783437.008

O'Hagan, T. (1999). The Arguments of the Philosophers: Rousseau. Routledge: London and New York.

Parry, G. (2006). Émile: Learning to Men, Women and Citizens. In P. Riley (Ed.), The Cambridge Companion to Rousseau (pp. 247-268). Cambridge: Cambridge University Press. https://doi.org/10.1017/CCOL0521572657.009

Quinton, A. (1996). Philosophical Romanticism. In T. Honderlich (Ed.), The Oxford Companion to Philosophy, Oxford: Oxford University Press.

Richardson, A. (2002). Mary Wollstonecraft on Education. In C. Johnson (Ed.), The Cambridge Companion to Mary Wollstonecraft (pp. 24-39). Cambridge: Cambridge University Press. https://doi.org/10.1017/CCOL0521783437.003

Rousseau, J. J. (1979). Émile (A. Bloom, trans.). New York, NY: Basic Books.

Rousseau, J. J. (1984). A Discourse on Inequality (trans. M. Cranston). London: Penguin Books. 
https://doi.org/10.15405/FutureAcademy/ejsbs(2301-2218).2012.3.6

eISSN: 2301-2218 / Corresponding Autho: Kamuran Godelek

Selection \& Peer-review under responsibility of the Editors

Rousseau, J. J. (2002). The Social Contract and First and Second Discourses (S. Dann, trans.). Yale University Press: New Haven and London.

Shell, S. M. (2006). Émile: Nature and the Education of Sophie. In P. Riley (Ed.), Cambridge Companion to Rousseau (pp. 272-294). Cambridge: Cambridge University Press.

Wexler, V. G. (2001). “Made for Man's Delight: Rousseau as Antifeminist. American Historical Review, 81(2), 266-291. https://doi.org/10.2307/1851171

Wollstonecraft, M. (1796). A Vindication of the Rights of Women with Strictures on Political and Moral Subjects. London: J. Johnson. 